\title{
PERSPECTIVE AS AN ARTISTIC TOOL OF COMPOSITION IN THE ENGRAVINGS BY GIOVANNI BATTISTA PIRANESI
}

\author{
Elena Chernaya \\ Saint Petersburg State University of Architecture and Civil Engineering \\ Vtoraja Krasnoarmejskaja ul. 4, St. Petersburg, Russia \\ elena.chernaya.75@mail.ru
}

\begin{abstract}
This study is devoted to the recreation of Giovanni Battista Piranesi's compositional thinking. The study is based on analyses of the composition of his engravings depicting architecture and space. Here Piranesi's compositional solutions for his graphic works are compared to his predecessors and contemporaries' beautiful paintings carrying the same motif. In order to show that the perspective was one of the artistic tools for him, the article presents the comparative analysis of one of Piranesi's engravings ("View of Basilica di San Paolo Fuori le Mura" from the series of "Views of Rome") with a perspective model made with the help of a SketchUp software, pictures of layouts and perspective views made with the help of an architect method (the method of the descriptive geometry).

The author builds his point of view on the fact that the plane comprises only such structural elements of the existing composition, which clearly reveal its space-dimensional features when compared with each other. To confirm this, the author proposes an approach implying that all the information fixed at the plane is considered to be a professional communicative means necessary for formation of space-dimensional representations in a human mind about a composition in the overall system of the drawing or the image.

In order to confirm this hypothesis, the author carried out an analysis of the Pantheon drawings made by Andrea Palladio di Pietro and Giovanni Battista Piranesi. Due to the fact that the composition information on the object is broken into pieces and is represented by the system of interrelated orthographic views on the architectural design (on the drawing), in the article we tried to find out the implied logic and the pattern of information disclosure by Giovanni Battista Piranesi with the help of projection views.
\end{abstract} image

Key words: compositional thinking, engraving, perspective, model, drawing, orthographic view, computer model,

\section{Introduction}

A great interest in the graphic heritage of Giovanni Battista Piranesi can be observed in present days. A lot of books on this subject were published by the following authors: S.A. Toropov (1939), L.A. D'yakov (1980), N.I. Sorokina (2013), A.V. Ippolitov (2013), etc.; also some exhibition catalogues were published by the State Hermitage Museum (in 1959 and 2012), the State Museum of the History of St. Petersburg (2008), the Pushkin State Museum of Fine Arts (1972, 2015), and some albums of engravings were published by German publishing house TACHEN (in 2001, 2006, 2000).

The review of Russian articles revealed two authors who dedicated their works to the art of Piranesi. N.I. Sorokina (2007a) who focuses on Piranesi's works in the con- text of the age of Enlightenment (N.I. Sorokina passed her Ph.D. defense on this subject in (2007b), and V.M. Uspensky (2012) who traced the influence of Antonio Canaletto's drawings on the engravings of Piranesi "Vedute di Roma" (manifested in borrowings of compositional schemes and elements of images as well as exaggerated scale tricks, etc.) in his studies.

The range of foreign articles on the above stated subject is divided into four groups. The first group of authors focused on the study of drawings (Minor, 2010).

The second group of researchers showed interest in the description of different series of Piranesi's engravings stored in different countries and features of the genre Capriccio (Stoppani, 2009; Marchesano, 2010). 
The third group of authors focused on the study of issues not directly related to the architectural arts, i.e. then existing structures depicted on the engravings of buildings with the aim to examine their technology (e.g., Pizzo, 2011).

The fourth group addressed the issue of space in the engravings of Piranesi concerning its various aspects in their articles, therefore solving different tasks in different aspects of the topic (Marcos, 2014; Stoppani, 2014).

One author from the latter group - Jung-Rak Kim - is an opponent to our research. He questioned the historical accuracy of graphic recreation of the architectural image of ancient Rome in the genre of "Capriccio". The author does not develop the issue of precise manifestation in the engravings, but focused on the artistic legacy of Panini (Kim Jung-Rak, 2013). In our study we tried to reveal the aspect of accuracy and its manifestation on the example Giovanni Piranesi's engravings.

In 1995 R. J Aitken defended his master's thesis in McGill University in Canada on a subject "Piranesi-Vico: "Il Campo Marzio". Foundations and the Eternal City (Giambattista Piranesi, Italy)" under the direction of Alberto Perez-Gomes; the thesis developed a phenomenological approach to the architecture and urban planning. The student offered the interpretation of Piranesi's engraving "Campo Marzio" with use of the stated method; he revealed multidimensional contextual links with the help of his scientific instruments concentrating his attention on details of the engraving (Aitken, 1995).

Readers of this article may be wondering what one more new publication on the famous graphic artist and architect can bring? The novelty of the article lies in the use of the author's method of visual analysis of composition of the engravings for disclosure of their patterns of arrangement of geometric structure of the composition affecting the formation of an image. The perspective is one of the graphic tools of composition. The work comprises comparative series of photographs (engravings, drawings and layouts) and a 3-D computer model (the ensemble of the St. Peter's Cathedral in Rome). Some issues as to the role of perspective as a means of composition in architectural graphics of Piranesi are touched upon.

The hypothesis of the study is the following: Piranesi's graphic culture was formed in the process of communication and work with artists of different directions of sculptural arts which in turn influenced the formation of compositional and creative thinking revealing in the methods of space arranging in his engravings. The desire to show and to provide insight into the idea of an existing space-dimensional composition (in motion) had a great effect on structure-forming principles of composition on his engravings, the transformation of visual perspective, the choice of emphases in the composition of depicted architectural forms.

Taking into consideration existing compositions and drawings, the analysis of motifs depicted at the engravings of Piranesi would help to identify peculiarities of visual thinking of the architect and features of a composition on the plane.
The space is one of the forms (along with the time) of existence of the infinite and ever-evolving world. It is characterized by length, volume, structure and limitation. Depicted space has its limits both visual and defined by an artist on the general layout. In the first case, the boundaries of an imaging area are delineated with a clarity of visual perception of the architecture depicted (boundaries of visual perception, fixing of the point of view, the level of the skyline on the plane). In the second case, the artist himself puts boundaries at the painting field, which is stipulated by the need for solving of some graphic tasks.

\section{Methods and materials}

The Fundamental library of the Saint Petersburg State University of Architecture and Civil Engineering stores 15 books with engravings by Giovanni Battista Piranesi. The series of engravings are as follows: "Prima Parte di archittura e Prospettive", "Vedute di Roma", "Grottesch", "Carceri", "Della maginficenza ed arcitettura di Romani", "Antichit a romane", "Antichit a della Magna Grecia", "Antichit a di Pompei", and the ones rarely published in modern editions such as "Alcune vedute di archi trionfali, ed altri monumenti inalsati da romani parte de quali si veggono in Roma,..." "Trofeo o sia magnifica Colonna coclide di marmot composta digrossi macigni ... ", "Diverse maniere d adornare I camini", etc. (see Figure 1).

The paper presents some parts of illustrated deluxe editions from the SPSUACE collection that clearly reveal the subject of this study. In particular we are interested not in the technique of perspective creation (from the course of the Descriptive Geometry), but in the perspective as a means for generating three-dimensional representations revealing the features of depicted architectural forms composition.

In order to identify patterns existing in the composition of Piranesi's engravings and especially peculiarities of use of the perspective, we applied in our study a method of comparison of models of depicted forms (author's drawings and diagrams, pictures of layouts, a computer model) with engravings by Piranesi. At the same time a single skyline plane level was considered during the visual analysis of engravings.

When arranging the image space of the engraving, Piranesi took into account a composition of the depicted architecture and spaces and put visual boundaries of depicted images on the orthographic plane and engraving, and fixed the skyline level at the picture plane. He applied these actions to orient in the existing space and to represent a three-dimensional composition on the sheet plane. The aerial perspective system involves division of the imaging space into plans. Such division may be stipulated with the features of the current composition of depicted architectural forms standing out from the environment due to their geometric, sculptural, and three-dimensional characteristics. These objects - elements form the structure of triple-planned composition of the engraving (see Figure 1, b, e). Besides, the geometric structure of the plane composition of Piranesi's engravings (see Fig.1) is divided into two types: 
a)
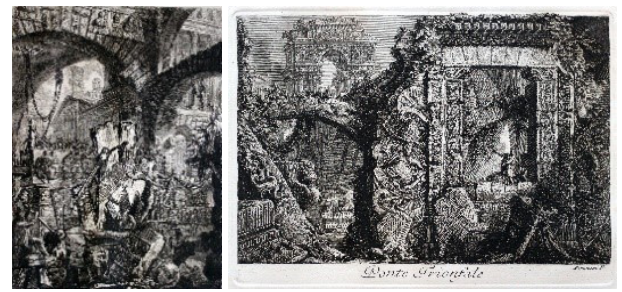

b)

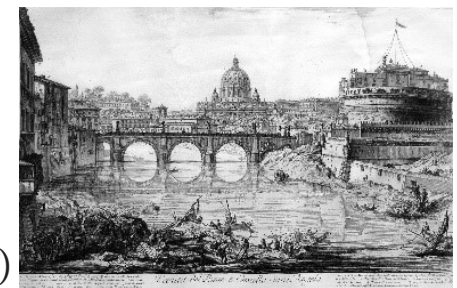

c)
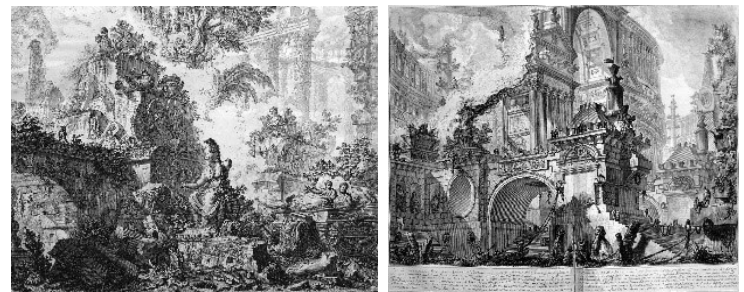

d)

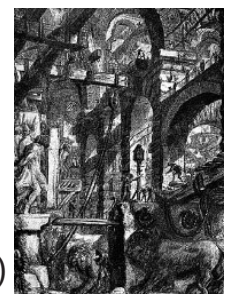

e)
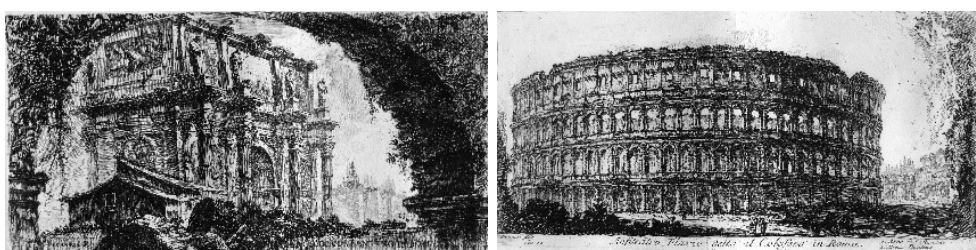

f)
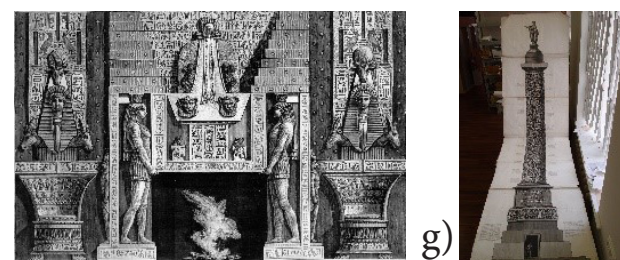

h)
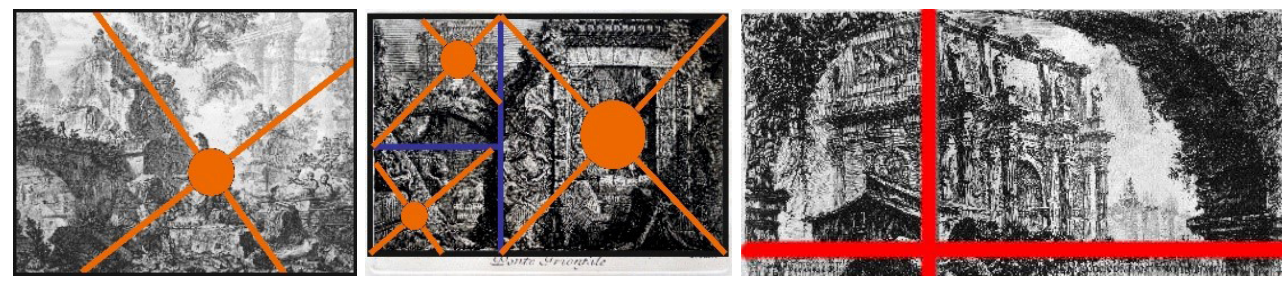

Figure 1. Examples of Giovanni Battista Piranesi's engravings from different series: a) "Prima Parte di archittura e Prospettive" (1975). The first part of architectural and perspective drawings made and engraved by Giovanni Battista Piranesi; b) "Vedute di Roma" (1748).

Views of Roman ancients; c) "Opere Varie di Architetturaprospettive grottechi,..." (1750). Different works of architecture, perspective, and classic ornamentations in the Ancient Roman style; d) "Carceri" (1760). Jail, drawings by Giovanni Battista Piranesi; e) "Alcune vedute di archi trionfali, ed altri monumenti inalsati da romani parte de quali si veggono in Roma,..." (edited after 1765). Some types of triumphal arches and other monuments built by the Romans, and a part of them is situated in Rome... $f$ ) "Diverse maniere $d$ adornare I camini"

(1769). Different ways of fire place decoration... g) "Trofeo o sia magnifica Colonna coclide di marmot composta digrossi macigni..."

(1770) (1773-1776). Trophies, or a magnificent twisted marble column made of big stone blocks; h) two types of a geometrical struc-

ture of the composition on the plane: with one compositional center; with a compositional center and sub-centers; axial composition

a) engravings with one compositional center - emphasized with the following:

- contrasting juxtaposition of one object to its surroundings by its geometric dimensions, sculptural characteristics or special location on the engraving outlined with cross-diagonals (see Figure $1 \mathrm{~h}$ );

- breakdown of the engraving into some sectors related to its borders and placement of sub-centers in their compositional structures (see Figure $1 \mathrm{~h}$ ).

b) engravings with a strong vertical and horizontal composition axes.

The main compositional center and structural crosspoints help the viewer to form a volume-and-spatial representation of the image space. We can assume that the following factors affect the number of plans at the engraving: an artistic task, the current composition of the archi- tecture; psychology and physiology of a human namely the George Miller's rule " $7 \pm 2$ " (which explains the adopted division of the image space into three plans on classic painting and engraving; these three plans are also divided into another three minor plans giving a total of nine).

One of the characteristic features of Piranesi's works is complex possession and knowledge of the perspective (inspective, linear, frontal, corner, and air perspectives). His works often possess aerial perspective (a method creating an illusion of spatial depth on a plane with the help of a tonal contrast), frontal perspective in which the main face of a building is shown frontally without any perspective distortions, and lateral lines are directed into the vanishing point as well as a corner perspective fixing the perception of an image under a certain angle (all visible parts and all planes of imaging of the object in this graphic system are reduced and seen in perspective). 
The history of the art involves a lot of systems seeking to capture space image of perspective, but the plane in all of them appears to be only a measure of the depth, borders and form sculpture.

Italian artists, the masters of "Capriccio" and "Veduta", were students of theatre designers and perspective artists as a rule. The family of Italian decorators Bibiena-Galia and the brothers Domenico and Giuseppe Valeriani were hugely popular in Italy. They created paintings for Venetian theaters, palaces and villas, the composition of which included somewhat fantastic architectural buildings often connecting elements of different styles. We are interested in a compositional connection of such elements and the methods of indicating the presence of such a system that Piranesi supposedly learned. Twelve sketches of theatrical scenery by Giuseppe Galli Bibiena are given on Figure 2. A sheet from the Hermitage shows work sketches reflecting the author's search for possible solutions for a composition of the depicted motif.

The history of the Figurative Art defines a diagonal as:

a) an element of a formal composition in the plane arranging its structure, binding and helping to match the main components and to direct visual movements from one element to another.

b) It identifies properties of a three-dimensional composition of depicted forms and the space revealing through the time from a fixed and from a dynamic viewpoint. According to the theory of perspective (the descriptive geometry), a diagonal in "arranging of depicted objects" can be viewed "in the form in which the items are represented when we are directly looking at them through the picture space" (Rynin, 1918, p.1).

However, Figure 2 (a) shows another logic of arrangement. The obelus, the arch and the colonnade are repeated elements that are differently arranged on the sheet having different spot areas. The diagonal on the picture we are studying is involved as a link element of the structure. Bibiena fixed the options of compositional search. These options of arrangement of elements on the plane (with respect to the drawing boundaries) and a connecting diagonal form different images of the space in the human perception. Sketches have different artistic expression associated with different degrees of the space restraint. A quick overview of sketches gives an impression of film advancing, but it is not in actual fact. These are sketch pictures fixing the author's intent and a drawing composition. The author's intent implies a visual structure of the master cross-point (a compositional center). Visually, the diagonal guides directly to the center along with the balance axis for the nearest elements. This structural unit contrasts with the environment by some geometric characteristics: square, spot configuration, rhythm, etc. (according to the principle "a subject - background").

Let us make a time jump and look at the art of icon painting, namely at a fragment of the Hagiographical Icon of Saint Sergius of Radonezh (mid XVlth century) (see Figure $2 b$ ), we can clearly see the common arranging of the compositional structure principle revealed in arrangement of architectural elements at the background of the icon (Matochkin, 2006).

Consideration of contrasting examples of art objects reveals the existence of a common language of the art and various compositional systems with its own postulates and principles having different visual tools (similar to semiotic text arrangement). The skill of image forming was honing within the framework of these compositional systems. In a similar way the classical architecture claims that "... the one not looking for new forms is seeking perfection in existing ones. All the proportions, ratio of masses, textures, and the spaces are inside the canonical Roman order solutions" (Revzin, 2013, p. 250). These words can be attributed to the art of engraving. Thus, we would search for individual solutions in the composition of engravings in comparison with the works of Piranesi's predecessors, who worked with the same motif.

Let us look at the biography of Giovanni Battista Piranesi (1720 - 1778) considering only those facts that affected the formation of his individual style. According to the monograph by N.I. Sorokina (2013), we may distinguish the following events of his life: he was born in Venice, where there was already a considerable experience in graphic engraving in the "veduta" genre. Giovanni Battista Piranesi was a fellow countryman of Giovanni Battista Tiepolo, Canaletto, Bernardo Bellotto and Francesco Guardi. His father Angelo Pi- a)

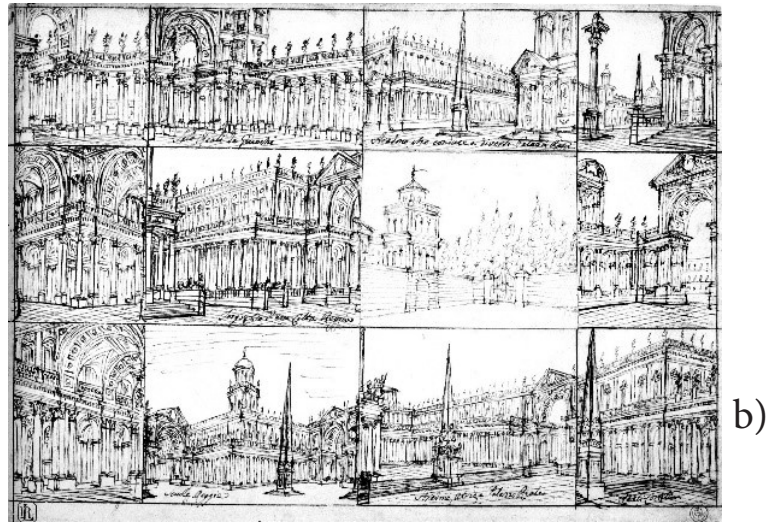

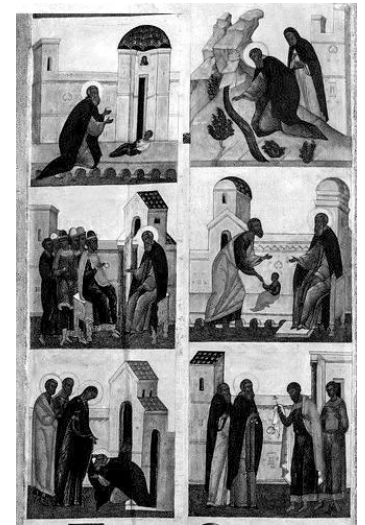

Figure 2. On the issue of common compositional structure of the Spatial Art works manifested in geometric combinations of elements of the compositional structure: a) Fernando Bibiena, XVIIth century; b) Fragments of the Hagiographical Icon of Saint Sergius of Radonezh (mid XVIth century) 
ranesi was a "mason", his mother Laura Piranesi was a sister of "the leading architect in the magistracy (Magistrato alle Acque)", engineer and architect Matteo Lucchesi; so, he was surrounded by architectural professionals and, subsequently, sought to continue the professional interests of the family. Piranesi learned the basics of the architectural profession and undertook practice under the guidance of his uncle. Piranesi became acquainted with the art of theater design and collaborated with Roman theatre designers Domenico and Giuseppe Valeriani. His first study visit to Rome was made in 1740. He participated as a draftsman of the incoming Venetian ambassador Francesco Venier. A few years later, Piranesi tried to find a job of an architect in Rome. His protector was Nikola Dzhiobbe, who had access to the library where engravings and books on history, architecture, antique case, and topography of Rome (graphic lists of Marco Ricci, Giovanni Battista Tiepolo, Luca Carlevarijs) were kept (Sorokina, 2013, pp. 7-8). We can assume that he saw the engravings of early and contemporary masters and was acquainted with ancient artifacts of the villa of Cardinal Alessandro Albani in Rome and participated at excavations of the villa of Roman Emperor Hadrian in Tivoli (Sorokina, 2013, p. 10). It is believed that his teacher was Giuseppe Vasi, the master of "viduta", an Italian graphic artist and painter.

Taking into consideration all of the above, the studies (Sorokina, 2013; Pizzo, 2011) and this article, it can be concluded that formation of Piranesi's creative method was influenced by the following art masters:

a) Francesco Galli Bibiena and Giuseppe Valeriani in the field of theater designing; b) Giovanni Antonio Canal called Canaletto, Giovanni Battista Tiepolo, Marco Ricci, Giuseppe Vasi, and others in the field of painting and drawing.

In order to identify the individual structure-forming principle of Piranesi's engravings, let us compare the image of architectural forms of arches, pyramids, and an amphitheater made by other painters and engravers.

The Dutch painter Caspar van Wittel (1653-1736) and the Italian painter Giovanni Paolo Panini (1691-1765) worked with the genres of "Caprichos" and "Veduta" before Piranesi (see Figure 3a). Their favorite motifs of imaging were ancient buildings: arches, colonnades, pyramids, circular buildings in the plan (the Colosseum, the Rotunda), amphitheaters, circuses, etc. Those architectural forms often turned into romantic ruins on their paintings and engravings. We studied the work of those artists, for example, depicting the Arch of Titus. We compared their works with the engraving by $G$. Battista Piranesi.

Wittel used frontal perspective in his works that dominated the linear perspective. Panini arranged his canvas composition otherwise applying angular perspective that created an illusion of dynamic motion at the plane, and the arch lost its qualities of severity and stability. Panini created dynamic tension of the composition enhancing diagonal directions and emphasizing functions of the arch skipping human flows and directing their movements. The works of those authors created the image of a closed architectural space with the help of extent and continuity of the silhouette of the architecture spot. a)

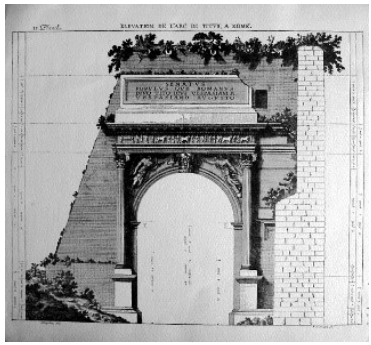

b)
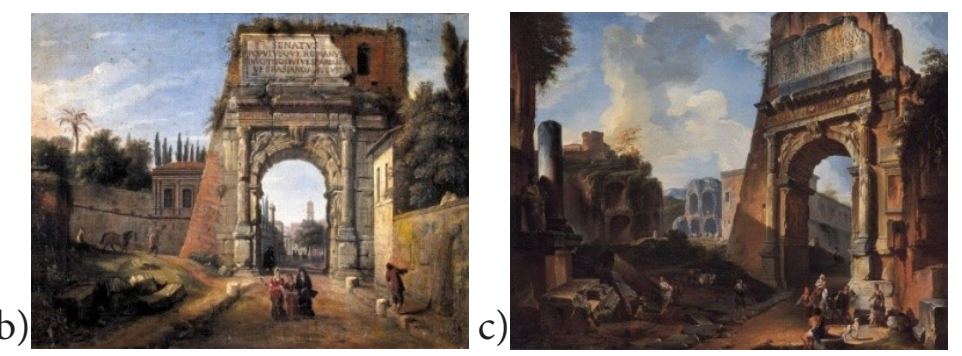

e)

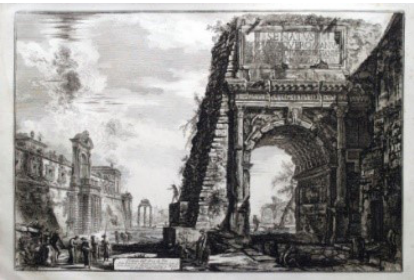

d)

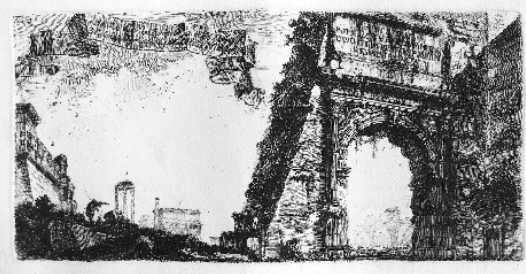

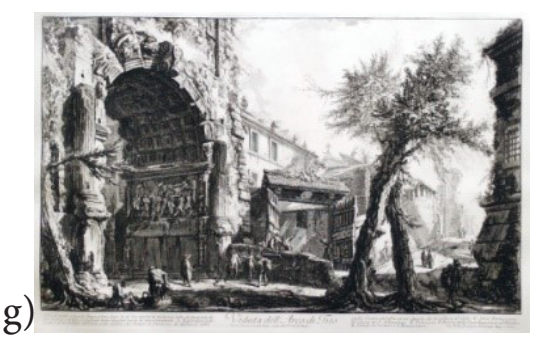

g) f)

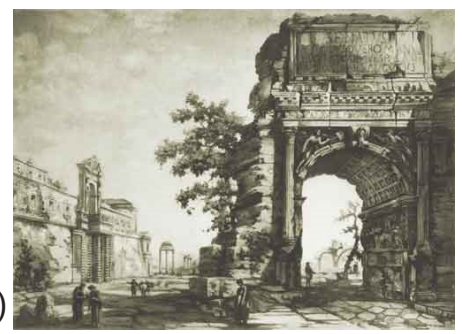

Figure 3. Works by Giovanni Paolo Panini and Giovanni Battista Piranesi: a) The Arch of Titus. Drawing; b) C. Wittel; c) G. Panini.; d, e, f) engravings by G. Battista Piranesi; g) V. Brenna. The Arch of Titus. Mural painting in the Anteroom of the Kamennostrovsky Palace. Made on the basis of G. Piranesi's engraving of 1796 (designed in 1781). Tempera on plaster 
Piranesi created his early engraving of the Arch of Titus (see Figure 3d) with application of an angular perspective having creatively interpreted the composition by $\mathrm{C}$. Wittel (Figures $3 \mathrm{~b}, \mathrm{c}$ ) by changing proportions of the work and the arch itself. In his works, Piranesi used sculptural and perspective contrasts of heights of buildings in the foreground relative to the second plan. This work comprises convergence of diagonal lines on the plane and angles of the depicted architecture joining in a point-axis of a formal composition, thus, separating the left and the right sides of the engraving. This indicates a twofold attitude towards the perspective as some kind of visual reality existing in the nature and as a means of formation of the composition structure on the plane. A few years later, he recognized this solution that he had found intuitively and subsequently developed in his new works on this motif. Piranesi generated a kinesthetic sense of motion within the composition of engravings in Figure $3(\mathrm{e}, \mathrm{h})$ using a contrast in the arrangement of the right and the left parts of the engraving (a contrast of emptiness and fullness). He created an impression of a guiding architectural space on the plane with the help of the grouping of basic volumes along boundaries of the drawing and the diagonal formed with the architecture silhouette. The diagonal in his work appears to be a visual boundary of the light and the shadow on the plane, on the one hand, and a visual means of a formal composition - a connecting axis leading to the two centers, on the other.

Another example is a drawing of the Pyramid of Caio Cestio (12 B.C.). In the IIIrd century A.D. the pyramid was connected to a wall built to protect the city against the growing threat of barbarian attacks. Emperor Honorius twice raised the height of Roman towers in the Vth century including the tower of the Eastern gates depicted on the engraving (Figure 4a, b, c, d). A visual range of Piranesi's works involving this motif shows another interesting a)

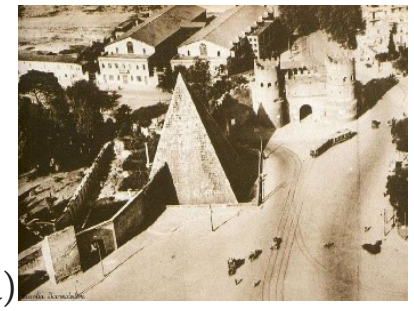

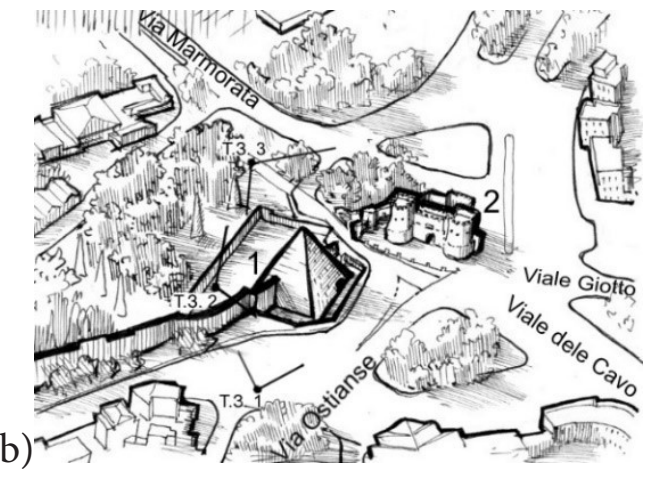

c)
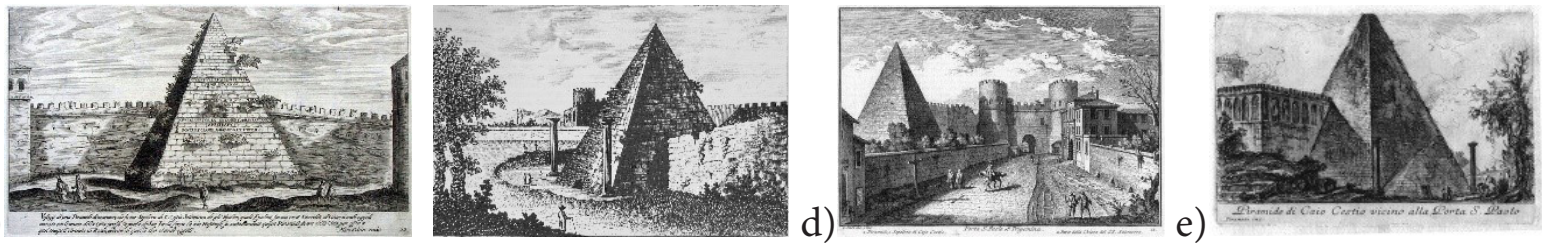

e)

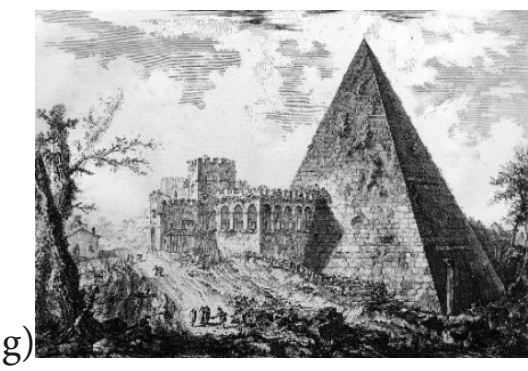

f)

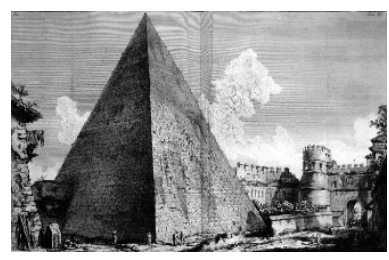

g)
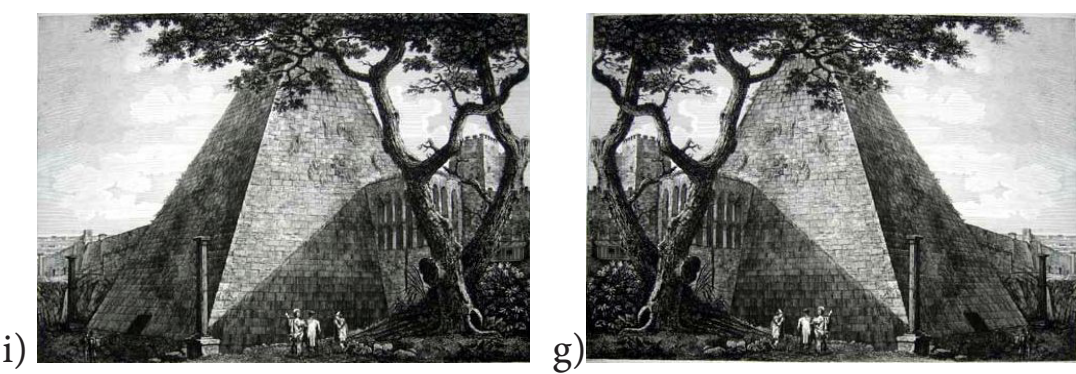

Figure 4. The Pyramid of Caio Cestio: a) a situational plan showing the pyramid and its surroundings b) the image of the pyramid at G. Battista Piranesi's engravings; c) Marco Sadeler (1606). The author of the second engraving is unknown; d) Giuseppe Vasi; e, f, g, h) Giovanni Battista Piranesi; i, j) by Luigi Rossini 
feature of his engravings. The first engraving - a small search for ideas - discloses geometrical features of the pyramid and the surrounding spaces (Figure $4 \mathrm{~h}$ ) in comparison with a subsequent large engraving (see Figure 4 e, f).The large engraving discloses information about the current architecture group. For that purpose, he introduced characteristic architectural elements carrying the information about the space around the pyramid (he broke and removed the right wall of the pyramid to the effect of outlining a three-dimensional composition). Considering Piranesi's staffage engravings, small architectural forms, trees, clouds and the rhythm of the shadows on buildings helped to reveal the information about the shape and the space, which could not be disclosed to the full through the use of visual means of perspective only. The details perform a connecting role in the structure of the work; they reveal an architectural (space-volumetric) and an artistic image.

We propose to perform a comparative analysis of Piranesi's and Rossini's works depicting the pyramid of Caio Cestio (see Figures $4 \mathrm{~h}$, i) to show the impact of details on the overall change of the image.

The Italian painter and architect of the XIXth century Luigi Rossini (1790-1857) was a follower of Piranesi's art; his engravings are often confused with the works of his predecessor. What is the reason for such similarity? Perhaps, it is in the repeating of compositional structure. For example, when copying and modifying one of the original composition sites (its geometry of structural sites), a new arrangement of a structure bearing a different view of the displayed three-dimensional composition and, hence, the whole image is created. Looking at the original work of Rossini (Figure 4j) and its mirror reflection (Figure $4 \mathrm{i}$ ), the compositional structure of the latter resembles the Piranesi's engraving on Figure 4 (h). Thus, Rossini repeated Piranesi's composition in its mirror reflection (see Figure $4 \mathrm{~h}$ ) having changed only the right part of the composition by adding a tree (see Figure $4 \mathrm{i}$ ). The Rossini drawing has the same level of the skyline in the picture plane as the Piranesi's work (see Figure $4 \mathrm{j}, \mathrm{g}$ ). The diagonal in the composition of his engravings connects structural elements and it interrupts not in the middle of the drawing like in Piranesi's work (by a diagonal of clouds), but at the edge of the image boundaries (by a diagonal of the tree).

In order to check our supposition, we reviewed another work by Luigi Rossini "Amphiteatrum Castrense" (see Figure $5 b, c)$. The arrangement of this work compiles compositional solutions of two works by Piranesi (see Figure $5 \mathrm{~b}, \mathrm{c}$ ); keeping their main structure, he corrected the details - architectural ones, trees, clouds, land topography (altering their geometry) - and formed a new image by changing the height of the skyline level at the engraving (see Figure 5d).

The method revealed in Luigi Rossini's work can form the basis for new training tasks for art restoration students aimed at creating a "sense of style", compositional styling skills and development of imagination. This does not imply the way of direct technical copying of a piece of work but studying of compositional principles of an artist in creation of architectural graphics and the way of creative interpretation of a composition on the basis of an original work.

Let us consider the existing methods of composition analysis for works of visual art. Nowadays, analysis of plane and formal composition and its constituent parts (lines, spots, etc.) is applied in theoretical and artistic studies of the works by S.M. Daniel', V.M. Mashkov,
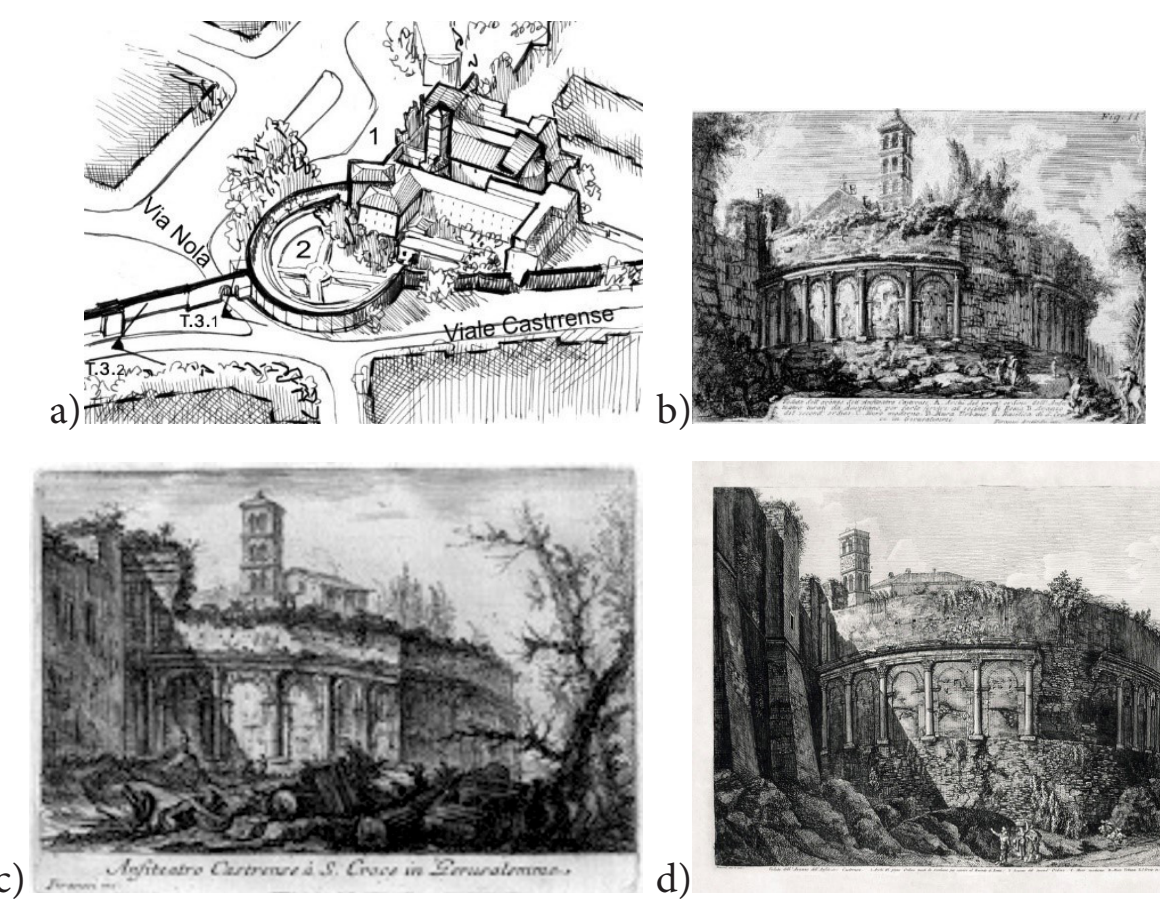

d)

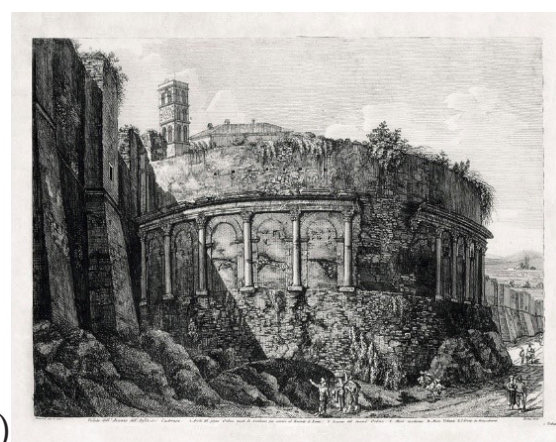

Figure 5. Site layout of the amphitheater Castrense; b) Engraving by G. Battista Pranesi; in) Agostino Tofanelli. Amphiteatrum Castrense (1833) 
O.I. Kuznetsov and others as well as when considering the structure and composition of paintings or engravings. The researchers studied patterns of arrangement of a "flat geometric structure", hidden rhythm schemes and spots in the works in question. A different type of analysis which is in contrast to the previous one can be seen in other works such as the works by V.A. Mel'nikov (2007) and L.S. Neyfakh (2009); this analysis implies a search for a "volumetric geometric structure" (search for patterns of arrangement of sculptural shapes, geometry, rhythm and principles of plane movement in three-dimensional forms). They recreated three-dimensional geometry of the shapes depicted on the drawing on the basis of reference points and lines of paintings and engravings trying to uncover the principles of plastic transforma- tion of the depicted shape. The researcher L.F. Zhegin (1970) proposed another method implying the display of a "geometric structure of force fields" on the considered sample of art. He applied the concepts and tools of the descriptive geometry (a vanishing point, a point of view, a visual ray) to reveal the features of hidden linear plastics of the composition of icons and frescoes. According to Zhegin, the arrangement of "developing" structure has planes and phases (see Figure 6).

Another research method - interpretation of a planar composition through a three-dimensional model (3-D) was offered to designer and architect students by A. Ephimov and N. Popova.

The following common principles are used by all researchers listed above: a)
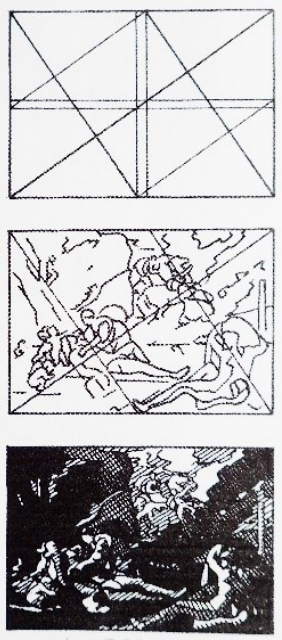

b)

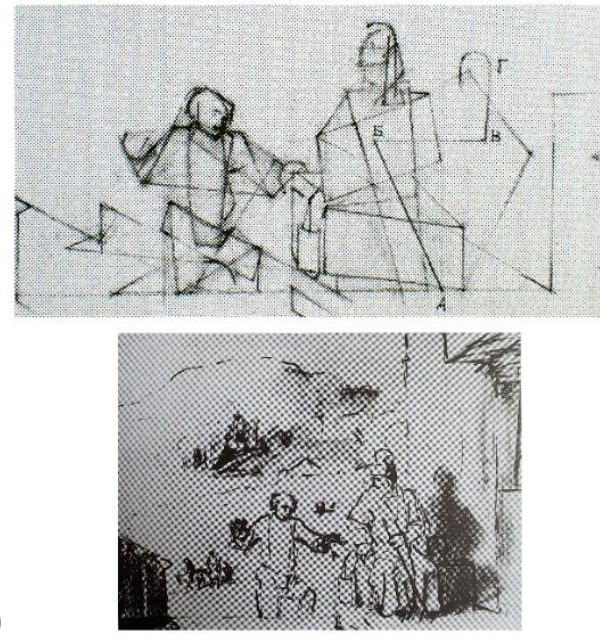

C)
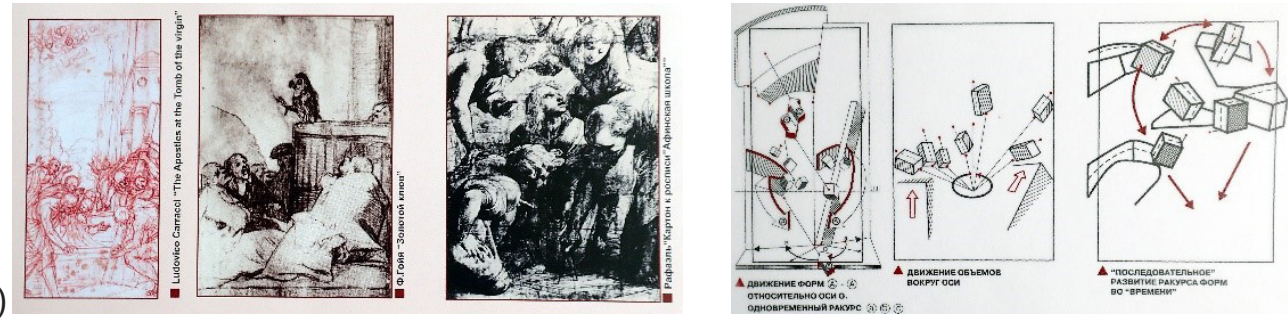

d)
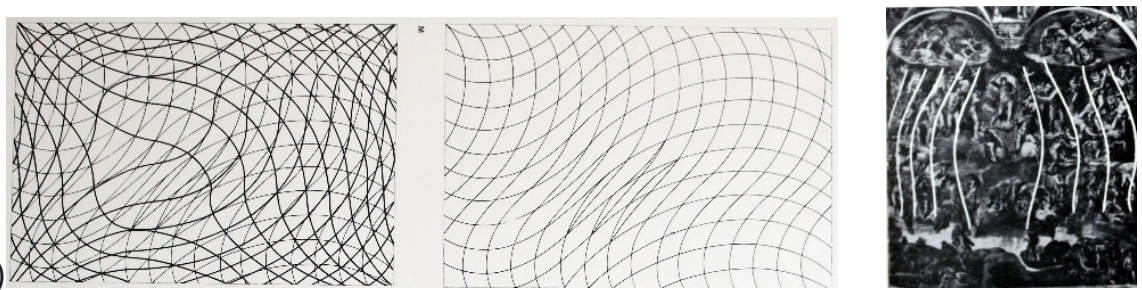

e)
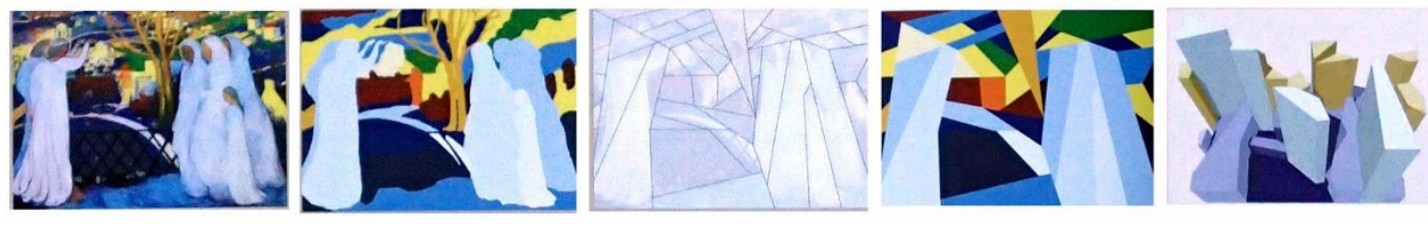

Figure 6. Methods of composition analysis of drawings and paintings: a) "plane geometric structure" (S.M. Daniel); b) "three-dimensional geometric structure" (L.S. Neyfakh); c) "principles of arrangement of three-dimensional geometric structures" (V.A. Mel'nikov, Ufa State Petroleum Technological University); d) "linear plastic structure of arrangement" in the work studied by L.F. Zhegin; e) interpretation of planar composition through three-dimensional formal model (A. Ephimov, N. Popova, Moscow Institute of Architecture) 
a) accurate repeating and generalized tracing of spots and lines of the forms depicted on the drawing;

b) search for a "key" of arrangement of three-dimensional and two-dimensional composition and integrity of the studied pieces;

c) analysis of one work and the omission of the entire heritage of the studied artist (see Figure 6).

V.I. Loktev proposed an original method for disclosure of an architectural composition of existing buildings built in the Baroque style. He explored the issue of artistic style in architecture, painting, sculpture, music and theatre design of XVI-XVII centuries on the basis of Italian art. He simulated graphical composition-and-image thinking on the basis of artist's diagram drawings depicting architecture particularly on the example of Michelangelo Buonarroti's art. Compositional thinking involves the process of searching for relations and subordination of parts between each other and to the whole by an architect. V.I. Loktev considers that this method is important for students of restoration of architect and architectural styles to enhance the process of studying architectural compositions (see Figure 7). We focused on his graphic method because he tried to find a form of verbal disclosure of the artist thinking aimed at disclosure of the arrangement structure of a building in his diagram drawings of buildings. He tried to capture the process of his visual thinking with the help of graphical outlining with arrows and brackets in order to analyze the composition of the building shifting the focus from one element to another and comparing them, and then making some conclusions. He directed the human glance to the object of consideration and its parts making at the same time small and large jumps (Yarbus). We can observe such jumps at Loktev's drawings in the process of professional analysis of fine arts. Thus, linear diagram drawings reveal his visual analytical actions, and particularly the comparison of the following:

a) small and large geometric breakdowns of forms in horizontal and vertical directions;

b) parts (architectural details) and small groups - units of forms between themselves and their breakdowns.

The research by V.M. Sonyak was dedicated to the analysis of the current composition of depicted architecture using orthographical views of drawings and perspective (Sonyak, 1985). Due to the fact that the studied architectural objects are not available to us, we needed to closely examine the drawings in our article.

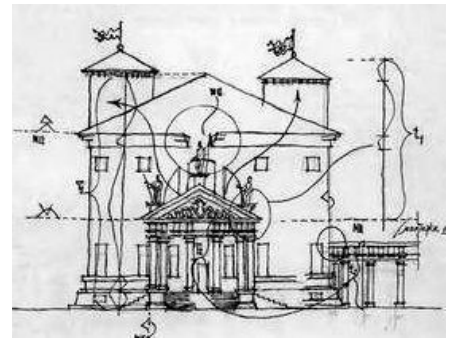

An image is a model of sensible space (A.V. Ikonnikov). As any other model, it implies similar reproduction of geometric, plastic and compositional characteristics of depicted forms and spaces on the plane. An image acts as a result of cognitive activity of a subject, its existing visual representations based on the long-term memory of the subject, on the one hand, and as a result of connection of the image boundaries on the plane of different temporal parts of the architectural form and space (elements), on the other.

An architect does not work directly with the material during the process of creating architectural forms, as a sculptor does for example. He uses graphics as a technical intermediary to visualize his perceptions of the future material shape and to deliver it to a consumer. Different art graphic means - composition, perspective, proportions, lights and shades, color, touches and texture, etc. - are used to activate the sense of materials on the plane. The artist arranges the system of work of these means in such a way that they affect the human mind and cause emotional and sensual reactions.

An architect uses graphic language as a communicative tool. He focuses his attention on some visual elements of the composition on the drawing and misses the others. Let us consider the architectural drawings of the Pantheon by Palladio Andrea di Pietro (1936) and Giovanni Battista Piranesi in order to identify the logic of disclosing information about the form with the help of view projections.

The fundamental treatise "The Four Books on Architecture" by Palladio tells us about the famous temple of Rome - Pantheon (named Rotunda in those periods of time), about its external and internal features of architecture, its shapes, decorations and design. The author gave an accompanying text to ten tables (drawings) in his work. The written list of the tables is quite interesting; it gives an idea of its compositional script of actions divided into the following three steps:

1) plan; the principle front; combination of the front and a cross-section revealing the structure of the shape;

2) side face; side section of the same face, features of the face decoration and details of the terrace;

3 ) cross-section of the main form in front of the entrance; interior fragments; details (ornaments) of the building interiors and the profiles of these ornaments (Matochkin, 2006).

We can affirmatively declare that the Pantheon drawings have a definite pattern. We used perspective ge-

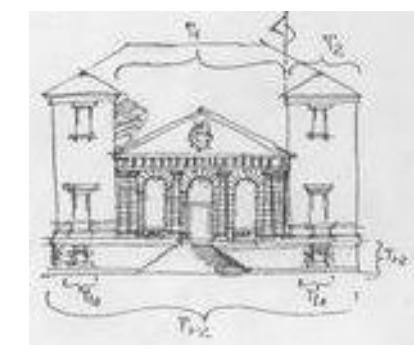

Figure 7. Method of analysis of an architectural building simulating the process of compositional thinking (V.I. Loktev) 
ometry, i.e. a simplified shape model of the Pantheon, to reveal this pattern. Schematic drawings captured the main volume of the buildings and the scene sequence of information disclosure on the object by means of a series of orthographic projections marked with certain figures; arrows detected visual documenting of external boundaries of the shape and interior space using indepth movement of the orthographic plane. The analysis of drawings revealed that the architect recorded each step and in-depth movement with the help of frontal and side views in order to disclose information about the shape of the object. Thereby, the scene abruption of in-depth movement put cross-longitudinal axes in motion (see Table 1).

The drawings by Giovanni Battista Piranesi retain the principle of jumps, on the one hand, but, on the other hand, they contain the innovative method of arrangement of architectural information about the object, i.e. the desire to fix the form and the space around it from all cardinal points. He opposes the projection of the drawing by 180 degrees. Due to this the architectural chart discloses the contrast information about the borders of the object both from the external point of view (see Table 1 , Figure 5, drawings $3,4,5,6$ ) and the inner point of view (see Table 1, Figure 5, drawings 1, 2, 7, 8, 9, 10, 11). Capturing of the whole shape, not individual parts of its external and internal appearance, was performed with the help of mirror opposing of its four projections. Almost all three-dimensional axes fixing the center and the borders of the object are applied. We can observe the method of contrast collision of opposites in Piranesi's art engravings, for example, linear and frontal perspectives (see Table 1, engravings 10, 11).

Let us suppose that the principle characteristic of Piranesi's architectural graphics was in his perspective views on engravings (to show compositional qualities of depicted objects from the moving point of perception). To check our hypothesis, we considered the engraving depicting the Basilica di San Paolo Fuori le Mura.

Basilica di San Paolo Fuori le Mura is one of four of the most considerable basilicas in Rome. It is located behind the Aurelius walls in the Southern part of Rome.

Table 1. Two contrasting methods of delivering of architectural information about the Pantheon on the basis of drawings by A. Palladio and G.B. Piranesi.

Andrea di Pietro Palladio. Venetia (1570) (drawings of the Pantheon in Rome from the book "The Four Books on Architecture" pp. 76, 77, 78) (Palladio, 1936)

Spatial models of phased transfer of information on the Parthenon in the drawing.

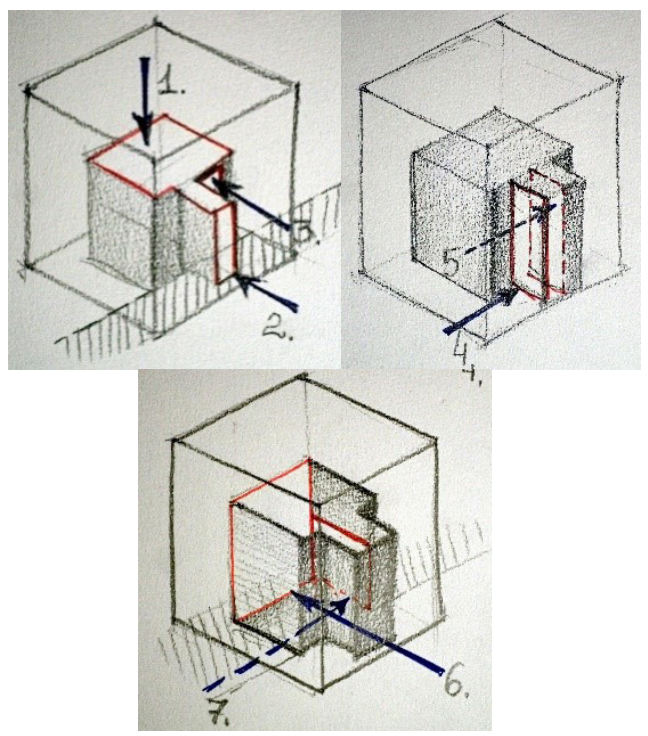

a)

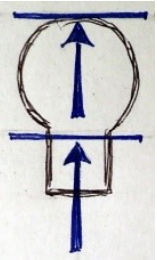

b)

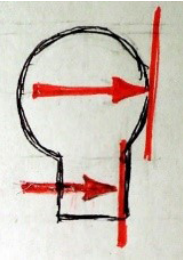

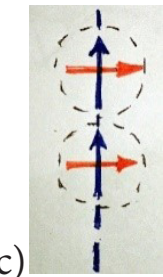

c)

The principle of the information transfer on the drawing - "Movement and stop (plane). Gradual in-depth and sideways movement fixing the spatial position of the form in its two plans). The sequence of information disclosure on the architectural form with the help of the drawing:

a) front faces and their sections;

b) the side faces and their sections;

c) axis of in-depth motion; fixing of the space with the help of crossing of contrasting front lines.

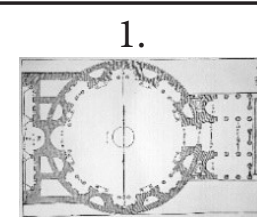

2.

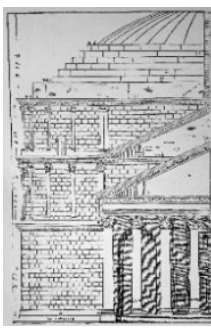

3.

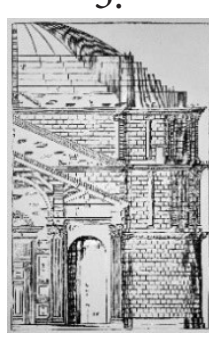

4.

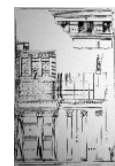

5.

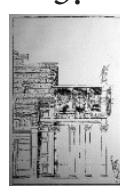

6.

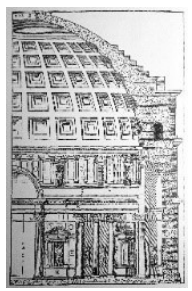

7.

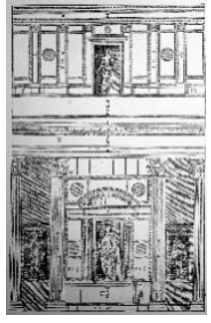


Table 1. Continued.

Giovanni Batista Piranesi (engravings from the book of prints stored in the SPSUACE)

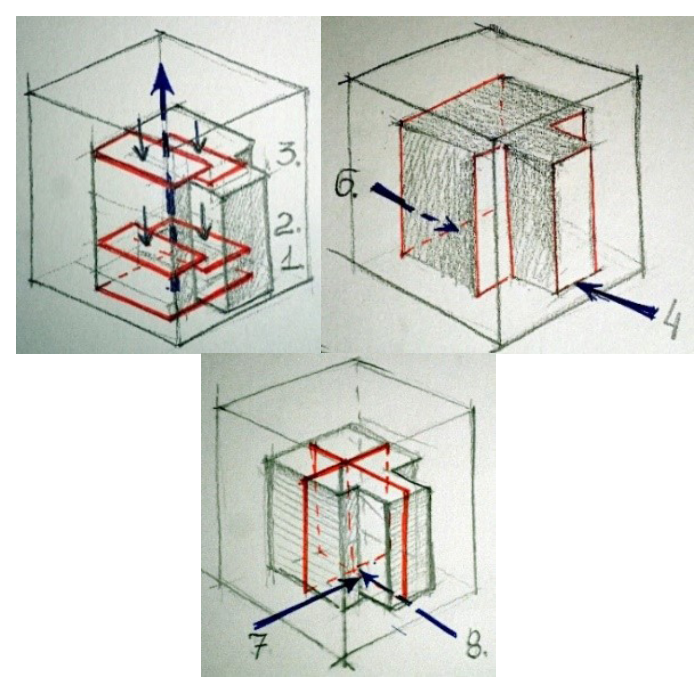

The principle of information transfer on the drawing - "opposition of forces" (contrasting viewpoints of the object and the interior, confrontation of internal and external spaces).

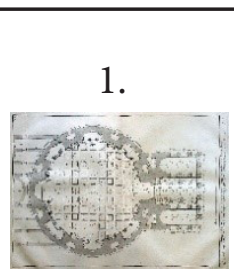

2.

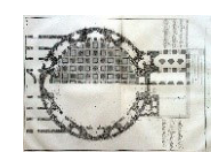

3.

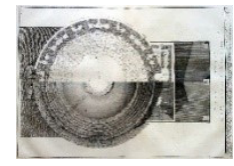

4.

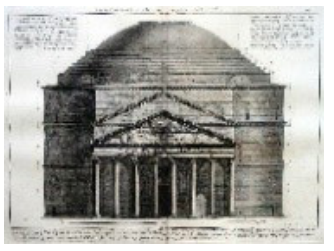

5.
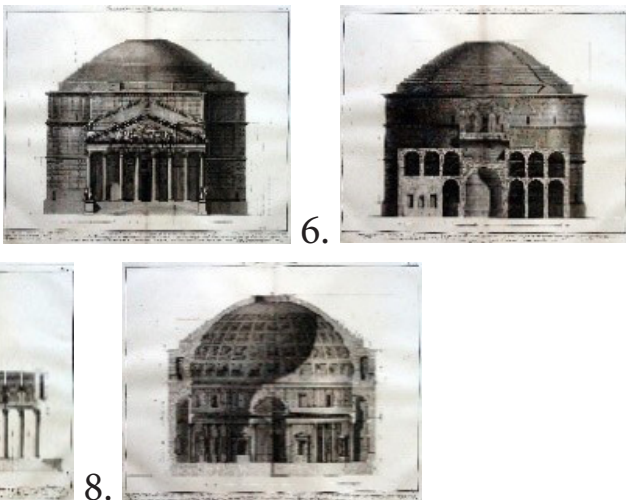

7.

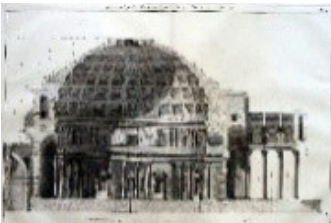

8.

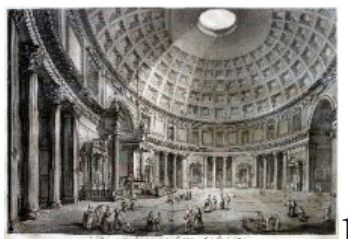

11.

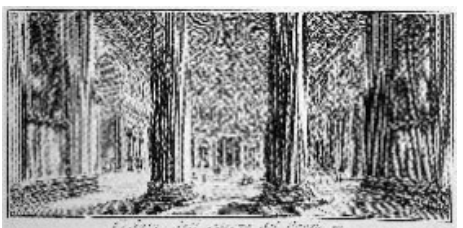

It was founded by the orders of Emperor Constantine in the beginning of IVth century at the ancient cemetery on the St Paul's tomb where remains of the Apostle were buried by the pious Roman matron Lucina as the tradition claims (Zimin, 2012). Unlike other patriarchal basilicas, St. Paul's Cathedral did not undergo any significant changes behind its wall during the Renaissance or the
Baroque era, but on July 15, 1823 it burned almost to the ground. Restoration of the basilica continued until 1840; meanwhile, a completely new classic facade was built which can be seen at the present days. The etching by Gaetano Cottafavi showed the Basilica di San Paolo Fuori le Mura in 1823 after a fire (See Figure $9 \mathrm{c}$ ). Thus, that basilica pictured on the engraving by Piranesi is not
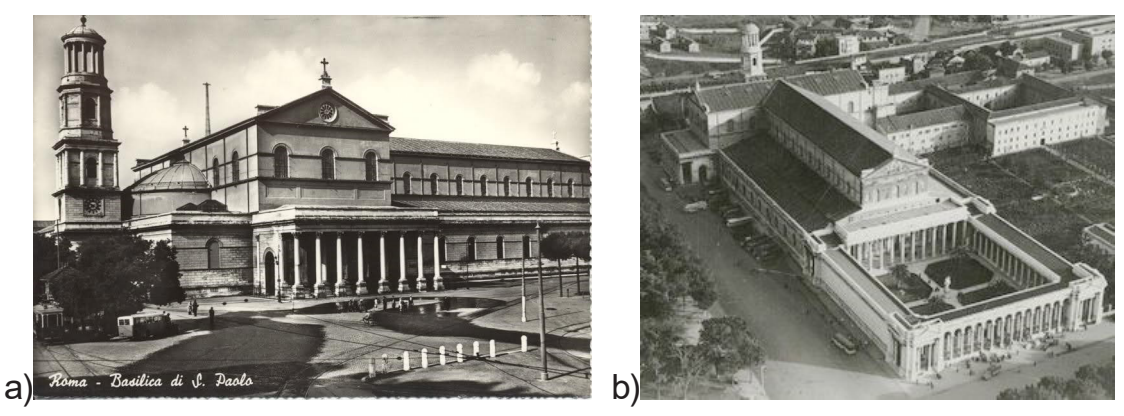

Figure 8. The Basilica di San Paolo Fuori le Mura: a) the present day entrance to the basilica; b) the former entrance to the basilica; the facade was reconstructed after the Fire of 1823 
a)
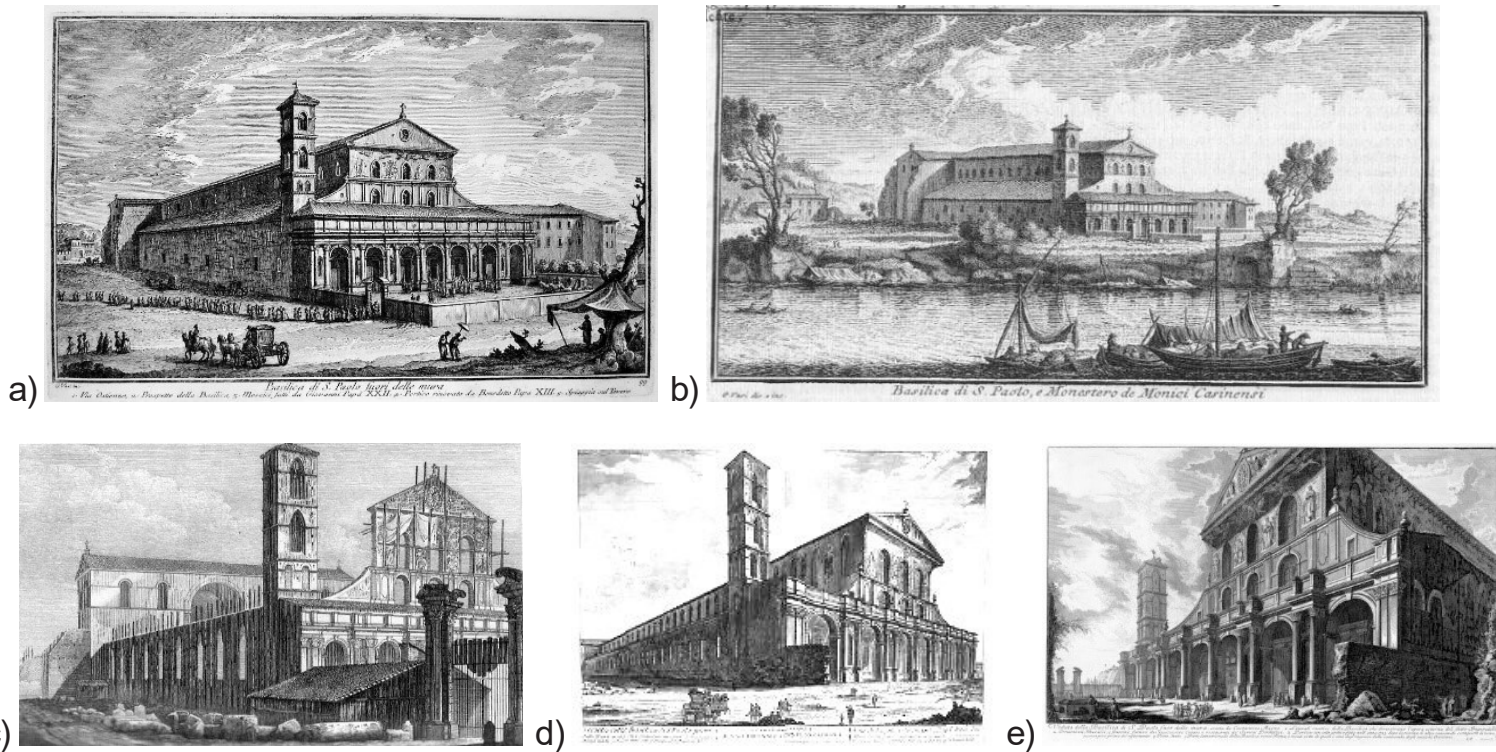

e)
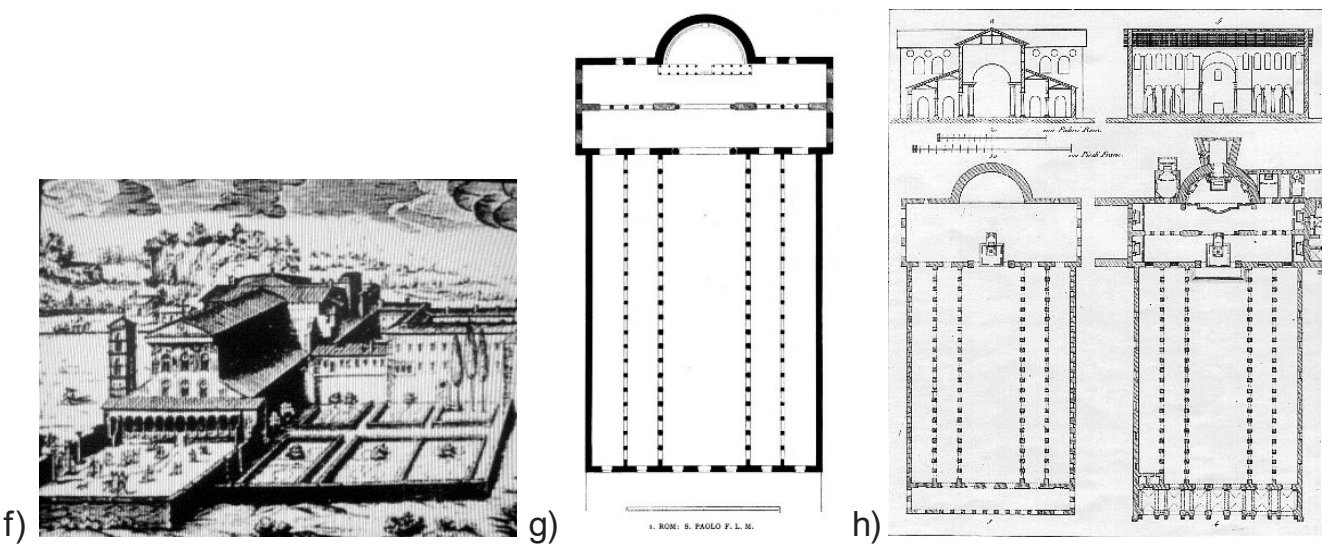

Figure 9. The image of Basilica di San Paolo Fuori le Mura on engravings:

a) by Giuseppe Vasi (1745-1765); b) The collection of the most beautiful vidutas of ancient and contemporary Rome on the basis of original engravings by Giuseppe Vasi; c) after the fire of 1823. Gaetano Cottafavi; d) Jean Barbeau (1748); e) G. B. Piranezi (1947), the series "Views of Rome"; f) an ancient engraving from a book. Data is not found yet. Layouts of Basilica di San Paolo Fuori le Mura: g) the layout (web resource); h) the Basilica layout before the fire (web resource)

available to us. The earlier front facade faces the Peristil yard now (see Figure 8).

Figure 9 presents the compiled materials of the engraving and drawings of Basilica di San Paolo Fuori le Mura. There are two engravings of the basilica performed by Piranesi (see Figure 10).

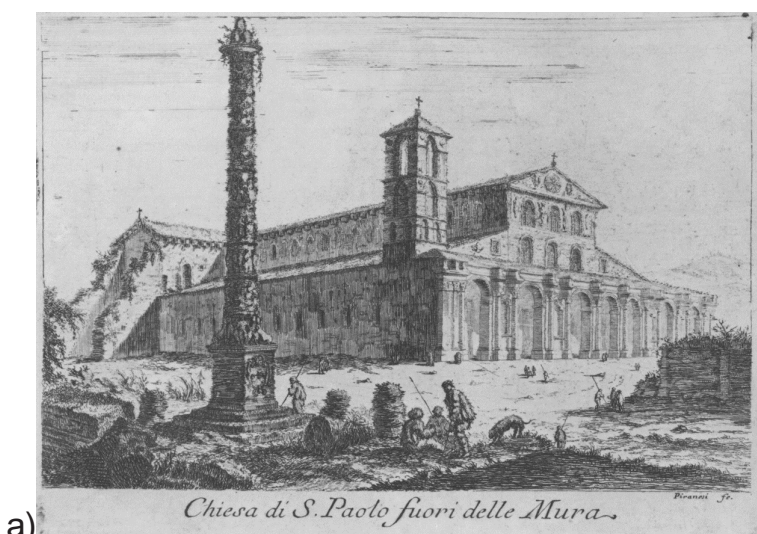

Figure 10. Basilica di San Paolo Fuori le Mura from the series "Views of Rome" by G. Battista Piranesi
Comparing Piranesi's engraving depicting the Basilica to previous works of other authors one can observe a fundamentally different solution. It implies creation of an impression of greatness of the Basilica at the picture space as a result of created completeness connecting all the elements carrying information on the following:

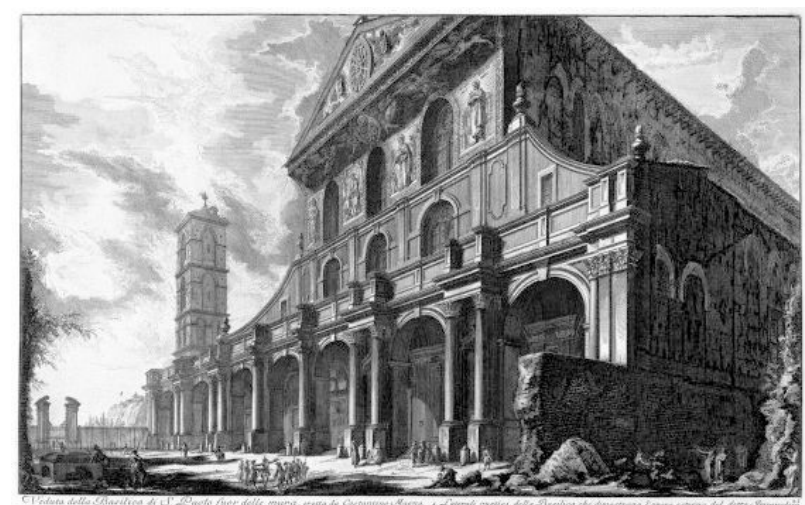

b) 
- the composition of the existing depicted form - information about the center, borders, and the space (its axes, breakdowns, rhythm, dominants, etc.);

- formal composition on the plane involving spots, lines, contrasts, perspectives, the composition center, structure elements, and the borders of the engraving.

When restoring vanishing points on the engraving and comparing it with the drawing (the layout of the Basilica), we came to the conclusion that there can be no such point at the skyline. The width of the gallery in the linear perspective should be greater as it is shown in Figure $11(a, c)$. The silhouette of longitudinal walls of the basilica should be different, not so triangular. That means that Piranesi changed the vanishing point in the right side having moved it closer to the central axis of the object for visual separation of the central part of the building (axes of perspective balance) to the effect of highlighting the center and the axis of the architectural composition (see Figure $11 \mathrm{a}, \mathrm{b}$ ).

a)

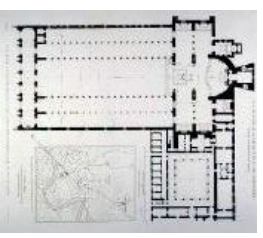

b)
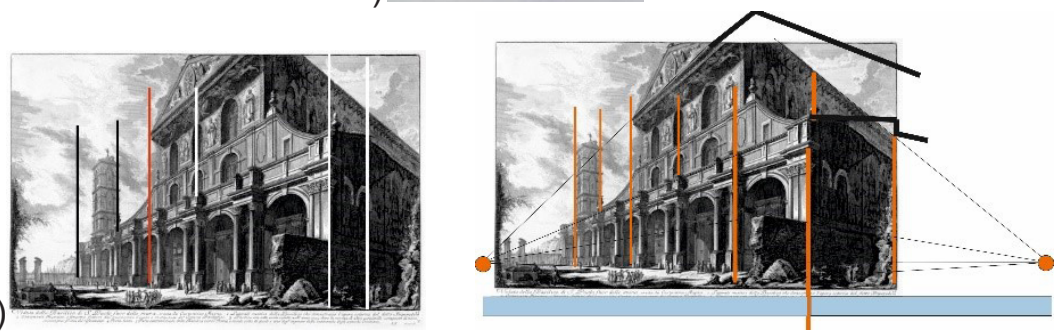

Figure 11. Analysis of the perspective of Basilica of San Paolo Fuori le Mura from the series "Views of Rome" by G. Battista Piranesi: a) the layout of the Basilica; b) analysis of the perspective

a)

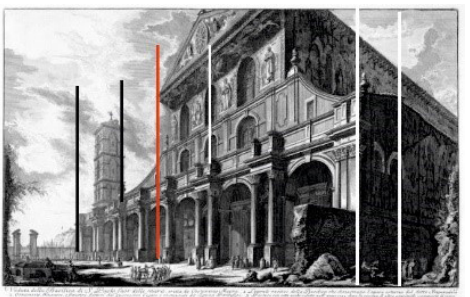

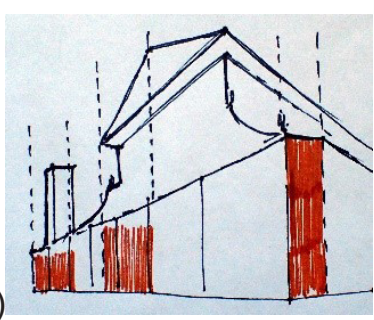

b) c)

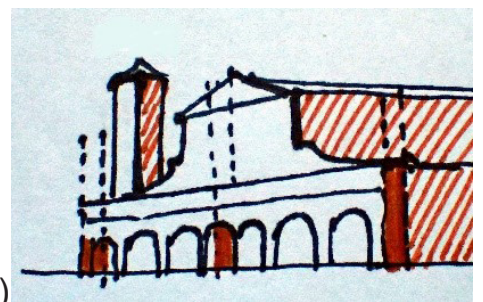

Figure 12. Use of the descriptive geometry methods for analysis of the perspective view of Basilica of San Paolo Fuori le Mura on the engraving by G. Battista Piranesi: a) engraving; b) drawing of the basilica perspective on the engraving showing a variable depth of the gallery; c) drawing of the basilica perspective built by the architect method (the method of descriptive geometry)
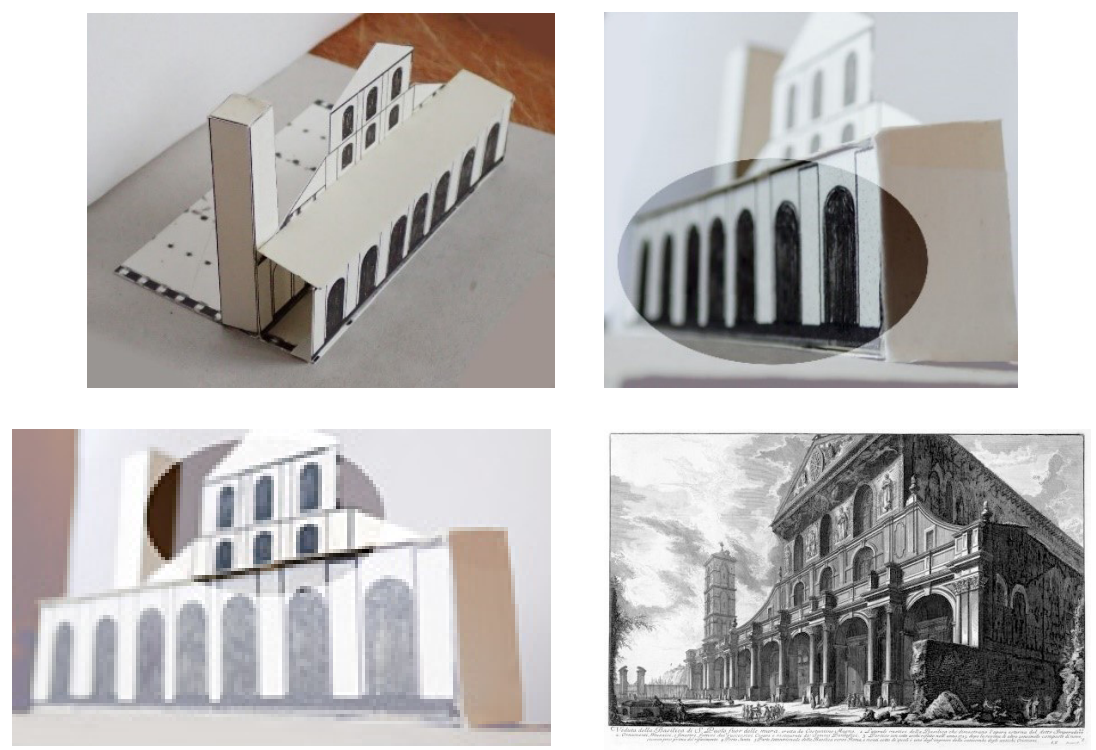

Figure 13. Using the architectural model for the analysis of perspective of the Basilica of San Paolo Fuori le Mura at G. Battista Piranesi's engraving; a) the working model; b) the view of the closed gallery similar to the view of the engraving from rhythmic row position; c) the view of arrangement of upper windows of the Basilica which is close to the solutions of the engraving 

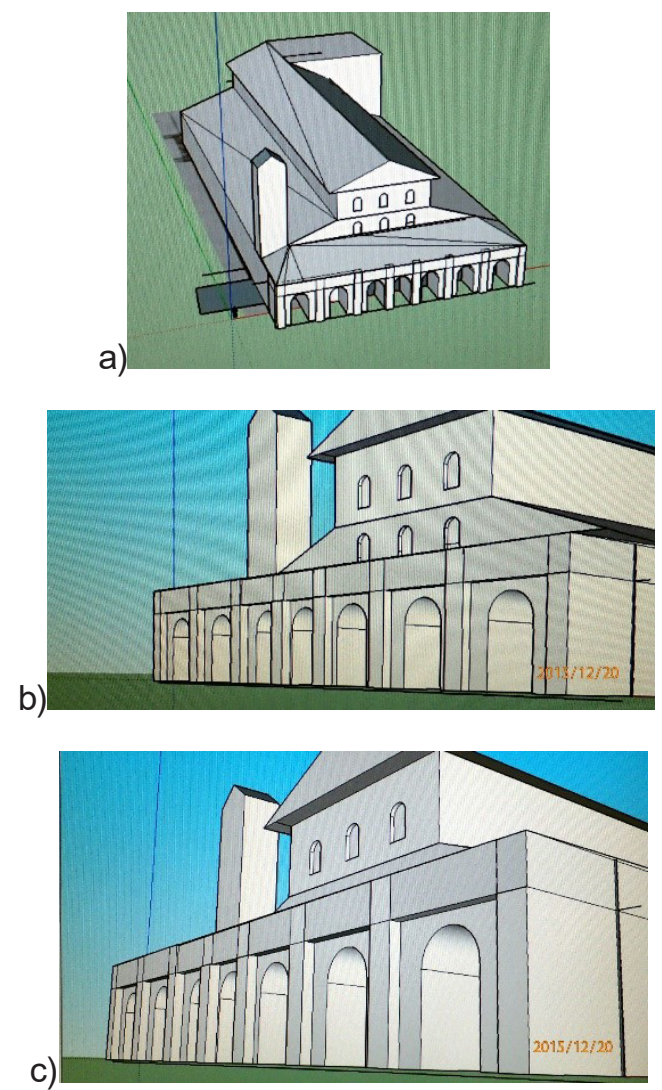
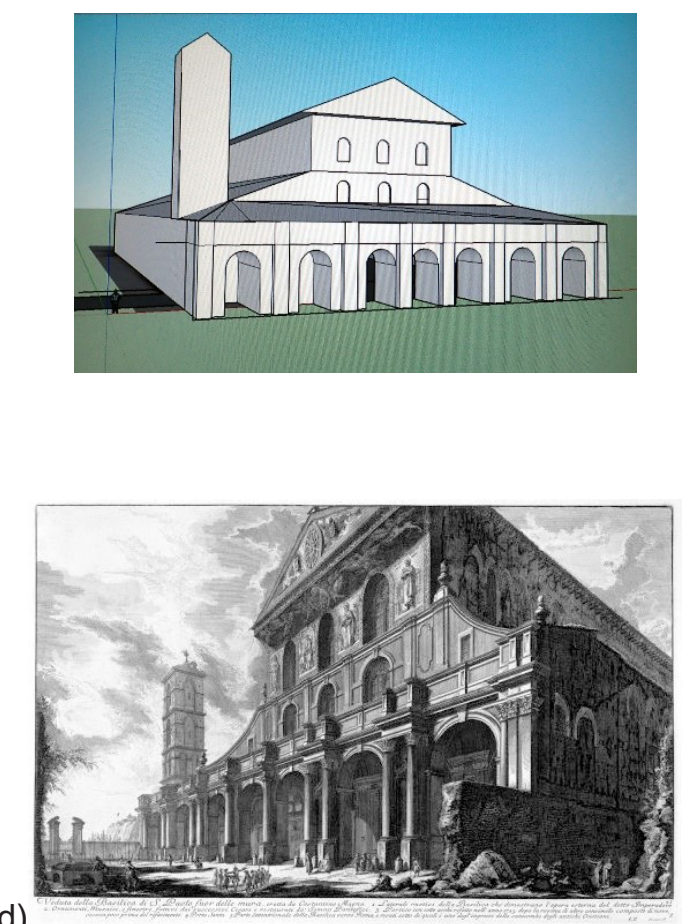

d)

Figure 14. Comparative analysis of the perspective view of the architectural form on graphic and computer models: a) the computer model of the Basilica of San Paolo Fuori le Mura (made in SketchUp); b) the computer model of the long-distance view of the basilica;

c) comparison of the perspective view of a computer model (of a short-distance view of the basilica) with the graphic model with respect to a skyline level

Figures 12,13 and 14 give the analysis of the perspective view of the basilica comparing it with the model performed in the perspective system of the descriptive geometry with the model pictures and the computer model.

Summarizing the above comments it can be concluded that a drawing (an orthographic view) served as a carrier of objective information about the depicted architecture for Piranesi. The architect transformed the visual perspective on the plane given all necessary drawing data or the full-scale study of proportions of the depicted form. He sought to convey a complete image comprising both artistic and creative initiatives and metric accuracy of architectural graphics; that is why Piranesi relied not on the visual information obtained from the fixed position, but on his special perceptions generated in the course of a longterm study of the models and samples of graphic arts of other artists.

Due to the fact that a drawing is a communicative way to record information about the object under study on the plane by decomposing it into parts (the orthographic view), this system is vulnerable to losses of visual integrity and breakdowns of ties between orthographic views. The history includes attempts to increase the integrity of segmental information such as integration of two or more views into one projection as it is on the drawing of XVIlth century (see Figure 15) (Mil'chik, 2008) and on the layout of the Pantheon dome performed by G. B. Piranesi (see Tables 1, 3).

The system of linear perspective of imaging the objective world on the plane is one-dimensional in accordance with the visual perception of objects by a man. It is rigidly tied to a view position and seemingly observed visual cut of sizes and shapes of an object in nature. According to the researcher V.M. Rozin, "the artist tries to convey the object viewed from different angles and at different times", "an image of the object (its general view) is compiled and summarized from various views" (integral views) obtained when viewing the object from different angles (from different sides). In this case, however, integrity of objective vision should be achieved, i.e. the object should be imaged as an integral whole, but not as composed of parts (although it is so according to contemporary visual establishments). Integrity of the objective vision was achieved in various ways in different cultures and at different stages of cultural development (Rozin, 2009, p. 97).

Piranesi used a perspective as a means of formal composition on a plane to join its geometric (consisting of centers, axes, groups and sites) and plastic structure (activating kinesthetic sense of motion on the plane "sculptural pattern"). His system of the perspective is multi-dimensional as he tried to render time - information about the shape from one fixed point meanwhile moving around it. The composition of the engraving comprises all elements selected 
a)

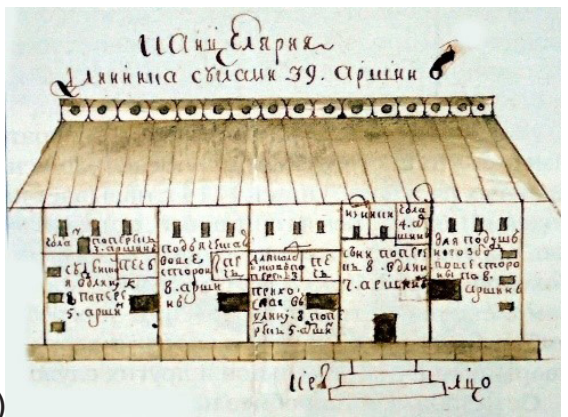

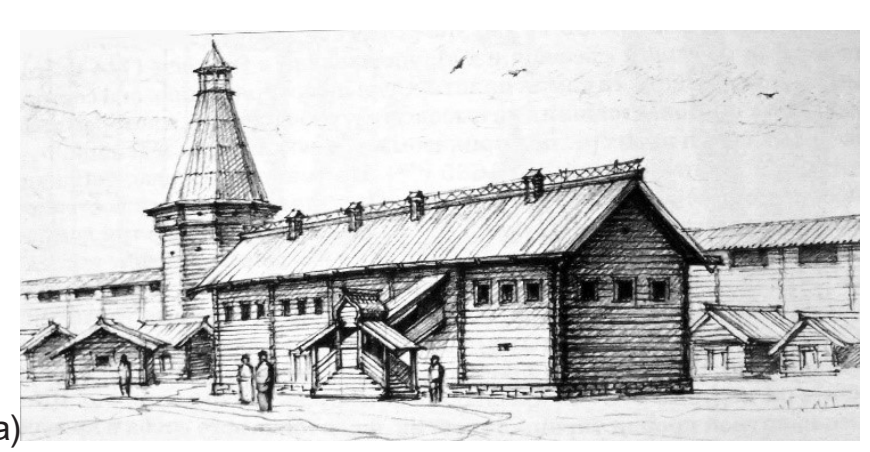

a)

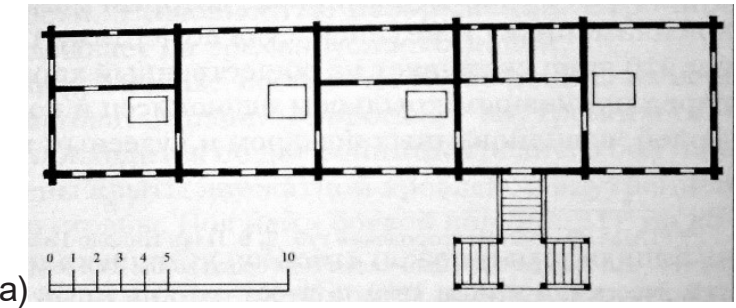

a)

Figure 15. Method of combination of visual and structural information about an architectural facility in one image on the example of draft drawing of the Decree chambers (Chancery): a) a drawing (1751), the Russian governmental library of ancient acts; b) graphic restoration of the Decree Chambers (M.I. Mil'chik and A.B. Bode); c) restoration of the layout of the Decree chambers (M.I. Milchik and A.B. Bode)

by the artist and bearing visual, geometric (orthographic) and spatial characteristics of the imaging ensemble.

Looking at the engravings of the San Paolo's Basilica and the St. Peter's Basilica in Rome, we can say that the author had a view of the space that he tried to render with all possible techniques. He used orthographic drawings as a model. "Conditionality of technical drawing generates a model or a scheme of an object" (Rozin, 2009, p. 102). When comparing proportions of the architecture depicted on the engraving with dimensions on the plan and on the face, we can clearly see geometric characteristics of the depicted forms that were important to him; this helps to understand the choice of architectural elements of the composition rendering the image of the form and the space. Comparing perspective view of the engraving and a three-dimensional model and a wide-angle photography, we are able to assess the degree of "objective vision integrity" and communicative precision of modeling of the depicted architectural form and space.

Prospective bounds between the elements in the composition of the engraving of the Basilica of San Paolo are divided, the elements carrying characteristic information on three-dimensional arrangement emphasize the architectural sculpture of walls and the composition of the existing space forms taking into account visual perception of the form in motion (determining the main and subsidiary viewpoints) of the depicted shapes. This is reached with the help of connection of two points of perception of the depicted object (face and side points). Two sculptural axes were activated in the formal compo- sition on the plane with consideration of its boundaries: vertical (in the central part of the basilica) and diagonal (perspective view).

Piranesi's method of architectural transfer of graphics was the integral part of his engravings - art images - as they revealed hidden compositional connections of the depicted architecture and the space.

\section{Conclusions.}

Summarizing the information in our research, we came to the following conclusions. G.B. Piranesi summed up the earlier experience of his predecessors and developed it in his art; they used the perspective as a visual means of composition on the plane necessary for creation of architectural (space-dimensional) and artistic images. The study revealed that the works by Piranesi (as well as by other artists of his era mentioned in the article) had the common idea of the perspective which is not a static system (for example, perspective in the descriptive geometry or in the computer graphics), but a flexible system that allows for recreation of a visual image or a model bearing geometric and three-dimensional characteristics of the architectural arrangement on the plane from the point of view of the observer.

\section{Results}

Results of the study can be used as additional material for teaching aids on the discipline "Drawing" and "Composition" focused on the disclosure of a particular compositional thinking of the architect. 


\section{References}

Aitken RJ (1995). "Piranesi-Vico: “Il Campo Marzio". Foundations and the Eternal City (Giambattista Piranesi, Italy). M. Arch. Thesis, McGill University, Montreal, Canada.

Bunin A (1935) Arkhitektura gorodskikh ansambley "Renessans" [Architecture of urban ensembles "Renaissance"]. Akad. kommun. khoz-va Izd-vo Vses. akad. arkhitektury; Moscow, USSR (in Russian).

Kim Jung-Rak (2013) A Study on the archaeological landscape-painting of the 18th century: Focusing on the Capriccio of Giovanni Paolo Pannini. The Journal of Art Theory \& Practice, 16: 175-199.

Loktev V (2004) Barokko ot Mikelandzhelo do Gvarini (problema stilja) [Baroque from Michelangelo to Guarini (the issue of style)] Tutorials for specialties "Architecture" and "Renovation and Restoration". Arkhitektura-S, Moscow, RF (in Russian).

Marchesano L (2010) Invenzioni capric di carceri: The Prisons of Giovanni Battista Piranesi (1720-1778). Getty research journal, iss. 2 : $151-160$

Marcos CL (2014) Imaginary Prisons or space as a topic. Disegnare idee immagini — ideas images, vol. 25, iss. 48: 44-55.

Matochkin Ye (2006) Obraz Prepodobnogo Sergija Radonezhskogo v russkom iskusstve [The image of St. Sergius of Radonezh in the Russian art]. Publishing House Agni, Samara, RF (in Russian).

Mel'nikov V (2007) Myslit' risunkom [Thinking by Image]. Oil and gas engineering, Ufa, RF (in Russian).

Mil'chik M (2008) Kargopol'. Derevjannaja krepost' i ostrogi po reke Onege [Kargopol. The wooden fortress and forts on the Onega River]. Views of Russia, Saint Petersburg, RF (in Russian).

Minor HH (2010) Designing Piranesi. Eighteenth-century life, vol. 34, iss. 3: 36-40.

Neyfakh L (2009) Nevidimye linii. Opyt graficheskogo analiza proizvedenij vizual'nogo iskusstva [Invisible lines. Graphical analysis of visual art]. Publishing House of SPbPU, Saint Petersburg, RF (in Russian).

Palladio A (1936) Chetyre knigi ob arhitekture Andrea Palladio, v koih posle kratkogo traktata o pjati orderah i nastavlenij naibolee neobhodimyh dlja stroitel'stva traktuetsja o chastnyh domah, dorogah, mostah, ploshhadjah, ksistah i hramah [Four Books on Architecture by Andrea Palladio, in which after a brief treatise on five orders and the most important instructions on construction it is rendered on private homes, roads, bridges, squares, xysti and temples]. Publishing house of the All-Russia Architecture Academy, Moscow, USSR (in Russian).

Pizzo A (2011) "The gallows are scaffolding". Giovanni Battista Piranesi and building techniques in Roman times. Archivo espanol de Arqueologia, 84: 267-283.

Revzin G (2013) Russkaja arhitektura rubezha XX-XXI v.v. [Russian Architecture at the turn of XXth and XXIth centuries]. Novoe izdatelstvo, Moscow, RF (in Russian).

Rozin V (2009) Vizual'naja kul'tura i vosprijatie. Kak chelovek vidit i ponimaet mir [Visual culture and perception: How one sees and understands the world]. 4th edition, suppl.. Publishing House LIBROCOM, Moscow, RF (in Russian).

Rynin N (1918) Perspektiva [The perspective]. Georgievsky Committee Printshop, Petrograd, RSFSR (in Russian).

Sonyak VM (1985) Metodicheskie razrabotki po plenernoy praktike [Tutorials on the plein-air practice]. Sverdlovsk Architectural Institute, Sverdlovsk, USSR (in Russian).

Sorokina N (2013) Dzhovanni Battista Piranezi [Giovanni Battista Piranesi]. BuksMArt Ltd., Moscow, RF (in Russian).

Sorokina NI (2007a) Tvorchestvo Dzh.-B. Piranezi v kontekste epokhi Prosvyashcheniya [Oeuvre of G.B.Piranesi in the light of the Renaissance]. Izvestiya Rossiiskogo gosudarstvennogo pedagogicheskogo universiteta imeni A.I. Gertsena [News of the Russian State pedagogical university named after A.I. Gertzen], vol. 13, n. 36: 127-139 (in Russian).

Sorokina NI (2007b) Tvorchestvo Dzh.-B. Piranezi v kontekste epokhi Prosvyashcheniya [Oeuvre of G.B. Piranesi in the light of the Renaissance]. Ph.D. thesis, Moscow, RF (in Russian).

Stoppani T (2009) Piranesi. The print collection of Ghent University. Journal of architecture, 14: 646-654.

Stoppani T (2014) Material lines: apocalypse, capricci, war and other disasters. Journal of Arcitecture, 19: 511-535

Toropov SA (1939) Dzhovanni Battista Piranezi: Izbrannye oforty [Giovanni Battista Piranesi: Selected etchings]. Vsesoyuznaya akademiya arkhitektury, Moscow, RF (in Russian).

Uspensky VM (2012) Venetsianskie vliyaniya v vidakh Rima Dzh. B. Piranezi [Venetian influences in the Roman views by G.B. Pianesi] Dom Burganova. Prostranstvo kultury [Burganov House. Cultural space], 1: 9-13. (in Russian).

Zhegin L (1970) Yazyk zhivopisnogo proizvedeniya: Uslovnost' drevnego iskusstva [The language of the piece of art: Conditionality of the ancient art]. Iskusstvo, Moscow, USSR (in Russian).

Zimin A (2012) Rim: Puteshestvie v Vechnyj gorod [Rome: The journey to the Eternal City]. NP-Print, Saint Petersburg, RF (in Russian). 